Acta Crystallographica Section E

Structure Reports

Online

ISSN 1600-5368

\section{(3S,6R)-3-Benzyloxymethyl-6-methyl- 1,4-dioxane-2,5-dione}

The chiral centres in the dilactone moiety of the title compound, $\mathrm{C}_{13} \mathrm{H}_{14} \mathrm{O}_{5}$, are in the configuration $3 S, 6 R$. The ring itself has a somewhat flattened twist-boat conformation. $\mathrm{C}-\mathrm{H} \cdots \mathrm{O}$ interactions join the molecules into a twodimensional network running parallel to the (101) plane.

${ }^{\mathrm{a} B i j v o e t}$ Centre for Biomolecular Research, Department of Crystal and Structural Chemistry, Utrecht University, Padualaan 8, $3584 \mathrm{CH}$ Utrecht, The Netherlands, and ${ }^{\mathbf{b}}$ Department of Pharmaceutics, Utrecht Institute for Pharmaceutical Sciences (UIPS), Faculty of Pharmaceutical Sciences, Utrecht University, PO Box 80082, 3508 TB Utrecht, The Netherlands

Correspondence e-mail:

h.kooijman@chem.uu.nl

\section{Key indicators}

Single-crystal X-ray study

$T=150 \mathrm{~K}$

Mean $\sigma(\mathrm{C}-\mathrm{C})=0.003 \AA$

$R$ factor $=0.031$

$w R$ factor $=0.076$

Data-to-parameter ratio $=8.9$

For details of how these key indicators were automatically derived from the article, see http://journals.iucr.org/e.
(C) 2005 International Union of Crystallography Printed in Great Britain - all rights reserved
Received 25 February 2005

Accepted 4 March 2005

Online 11 March 2005

\section{Comment}

The structure of the title compound was determined in the course of our investigations towards a better understanding of the regioselectivity observed in the ring-opening polymerization of the title compound, (I) (Leemhuis et al., 2005).<smiles>C[C@@H]1OC(=O)[C@H](COCc2ccccc2)OC1=O</smiles>

(I)

The sample from which the crystals were grown was synthesized from enantiopure (2S)-3-benzyloxy-2-hydroxy propanoic acid and $( \pm)-\alpha$-bromopropionyl bromide. The stereoisomers of this reaction were separated by column chromatography. The absolute configuration of the chiral centres in the dilactone moiety was chosen in accordance with the enantiopure starting material. The configuration of the chiral atom $\mathrm{C} 2$ is $R$; that of $\mathrm{C} 5$ is $S$. The structure of the $S, S$ stereoisomer has also been determined and is published in a separate report (Kooijman et al., 2005). The lactide ring has a somewhat flattened twist-boat conformation, as is common for $3 S, 6 R$-substituted lactides (e.g. Bolte et al., 1994). The maximum deviation of the ring atoms from the least-squares plane through the lactide ring is 0.1402 (14) $\AA$ for O3. The lowest asymmetry parameters (Duax \& Norton, 1975) are $\Delta C_{2}(\mathrm{C} 1)=3.24(16)^{\circ}$ and $\Delta C_{2}(\mathrm{C} 2-\mathrm{O} 3)=4.0(2)^{\circ}$; all other asymmetry parameters have values above $10^{\circ}$. The Cremer \& Pople (1975) puckering parameters are $\theta=90.3$ (3) and $\varphi=$ $330.9(4)^{\circ}$; the ideal values for this particular twist-boat conformation are $\theta=90^{\circ}$ and $\varphi=330^{\circ}$. The link between the two ring systems is not in an all-trans conformation; the torsion angles $\mathrm{O} 2-\mathrm{C} 5-\mathrm{C} 6-\mathrm{O} 5, \mathrm{C} 6-\mathrm{O} 5-\mathrm{C} 7-\mathrm{C} 8$ and $\mathrm{O} 5-\mathrm{C} 7-\mathrm{C} 8-\mathrm{C} 9$ all take the +gauche conformation.

The packing displays short $\mathrm{C}-\mathrm{H} \cdots \mathrm{O}$ contacts, geometric details of which are given in Table 2 . The $\mathrm{C} 2-\mathrm{H} 2 \cdots \mathrm{O} 2(1+x$, $y, z)$ contacts join the molecules into an infinite chain in the [100] direction, and the $\mathrm{C} 10-\mathrm{H} 10 \cdots \mathrm{O} 4(x-1, y+1, z)$ 


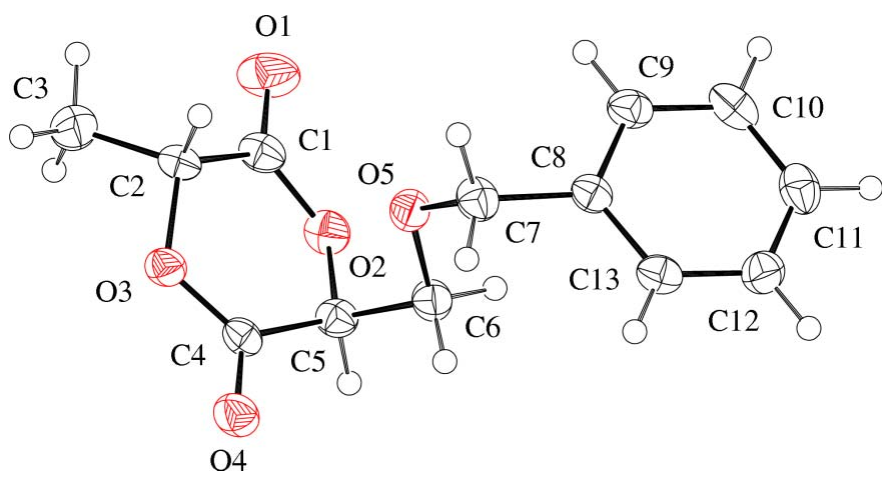

Figure 1

Atomic displacement plot (Spek, 2003) of the title compound, showing the atom-numbering scheme. The displacement ellipsoids are drawn at the $50 \%$ probability level.

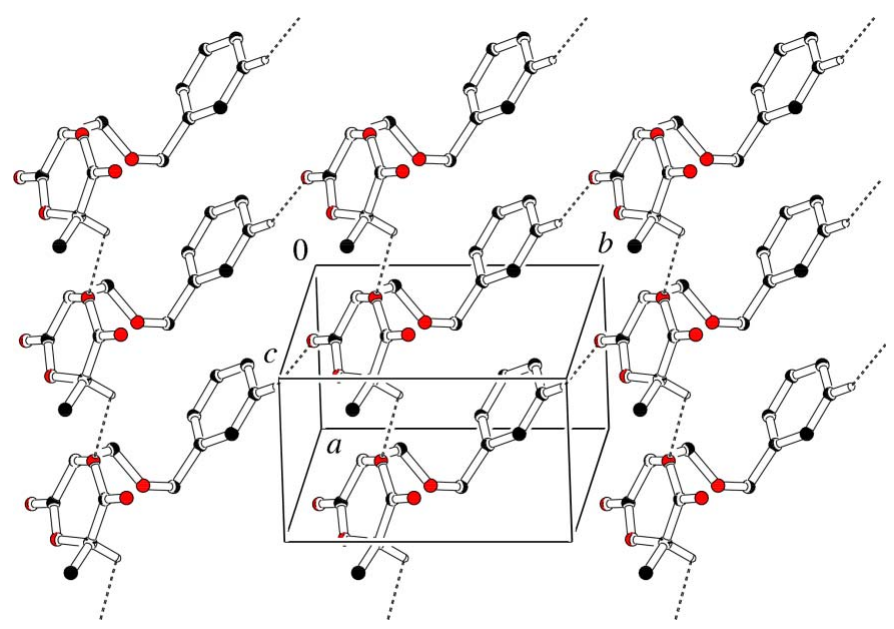

Figure 2

Short contacts $[\mathrm{C} 2-\mathrm{H} 2 \cdots \mathrm{O} 2(1+x, y, z)$ and $\mathrm{C} 10-\mathrm{H} 10 \cdots \mathrm{O} 4(x-1, y+1$, $z$ ), dashed lines] link the molecules into a two-dimensional network, parallel to the (101) plane.

contacts join the molecules into an infinite chain in the [110] direction. The combination of these chains generates a twodimensional network, parallel to the (101) plane (Fig. 2).

\section{Experimental}

The synthesis of the title compound is described elsewhere (Leemhuis et al., 2003). Crystals were grown from a sample obtained by vacuum distillation of the crude compound. To a solution of the refined product in methyl-tert-butyl ether some hexane was added. This solution was placed in a refrigerator and after a few hours colourless crystals were formed.

Crystal data

$\mathrm{C}_{13} \mathrm{H}_{14} \mathrm{O}_{5}$

$M_{r}=250.24$

Monoclinic, $P 2_{1}$

$a=5.289(2) \AA$

$b=8.678(2) \AA$

$c=13.178(5) \AA$

$\beta=96.748(12)^{\circ}$

$V=600.7(4) \AA^{3}$

$Z=2$

\author{
$D_{x}=1.383 \mathrm{Mg} \mathrm{m}^{-3}$ \\ Mo $K \alpha$ radiation \\ Cell parameters from 156 \\ reflections \\ $\theta=2.0-25.0^{\circ}$ \\ $\mu=0.11 \mathrm{~mm}^{-1}$ \\ $T=150 \mathrm{~K}$ \\ Block, colourless \\ $0.25 \times 0.10 \times 0.05 \mathrm{~mm}$
}

\author{
Data collection \\ Nonius KappaCCD area-detector \\ diffractometer \\ $\varphi$ scans, and $\omega$ scans with $\kappa$ offsets \\ Absorption correction: none \\ 16381 measured reflections \\ 1464 independent reflections
1308 reflections with $I>2 \sigma(I)$
$R_{\text {int }}=0.056$
$\theta_{\text {max }}=27.5^{\circ}$
$h=-6 \rightarrow 6$
$k=-11 \rightarrow 11$
$l=-17 \rightarrow 17$ \\ Refinement \\ Refinement on $F^{2}$ \\ $R\left[F^{2}>2 \sigma\left(F^{2}\right)\right]=0.031$ \\ $w R\left(F^{2}\right)=0.076$ \\ $S=1.07$ \\ 1464 reflections \\ 164 parameters

$$
\begin{aligned}
& w=1 /\left[\sigma^{2}\left(F_{\mathrm{o}}^{2}\right)+(0.0473 P)^{2}\right. \\
& \quad+0.02 P] \\
& \text { where } P=\left(F_{\mathrm{o}}^{2}+2 F_{\mathrm{c}}^{2}\right) / 3 \\
& (\Delta / \sigma)_{\max }<0.001 \\
& \Delta \rho_{\max }=0.12 \mathrm{e} \AA^{-3} \\
& \Delta \rho_{\min }=-0.18 \AA^{-3}
\end{aligned}
$$

$\mathrm{H}$-atom parameters constrained

Table 1

Selected geometric parameters $\left(\AA,^{\circ}\right)$.

\begin{tabular}{lrlr}
\hline $\mathrm{O} 2-\mathrm{C} 1$ & $1.336(2)$ & $\mathrm{O} 3-\mathrm{C} 2$ & $1.450(2)$ \\
$\mathrm{O} 2-\mathrm{C} 5$ & $1.440(2)$ & $\mathrm{O} 3-\mathrm{C} 4$ & $1.326(2)$ \\
$\mathrm{C} 1-\mathrm{O} 2-\mathrm{C} 5$ & $121.33(13)$ & $\mathrm{C} 2-\mathrm{O} 3-\mathrm{C} 4$ & $121.39(13)$ \\
& & & \\
$\mathrm{C} 7-\mathrm{O} 5-\mathrm{C} 6-\mathrm{C} 5$ & $163.22(14)$ & $\mathrm{O} 2-\mathrm{C} 5-\mathrm{C} 6-\mathrm{O} 5$ & $66.08(16)$ \\
$\mathrm{C} 6-\mathrm{O} 5-\mathrm{C} 7-\mathrm{C} 8$ & $57.98(19)$ & $\mathrm{O} 5-\mathrm{C} 7-\mathrm{C} 8-\mathrm{C} 9$ & $66.3(2)$ \\
\hline
\end{tabular}

Table 2

Hydrogen-bond geometry $\left(\AA,^{\circ}\right)$.

\begin{tabular}{lllll}
\hline$D-\mathrm{H} \cdots A$ & $D-\mathrm{H}$ & $\mathrm{H} \cdots A$ & $D \cdots A$ & $D-\mathrm{H} \cdots A$ \\
\hline $\mathrm{C} 2-\mathrm{H} 2 \cdots \mathrm{O} 2^{\mathrm{i}}$ & 1.00 & 2.60 & $3.152(2)$ & 115 \\
$\mathrm{C} 10-\mathrm{H} 10 \cdots \mathrm{O} 4^{\mathrm{ii}}$ & 0.95 & 2.57 & $3.465(3)$ & 158 \\
\hline
\end{tabular}

Symmetry codes: (i) $x+1, y, z$; (ii) $x-1, y+1, z$.

In the absence of significant anomalous scatterers, Friedel pairs were averaged. The methyl group was refined as a rigid group, allowing for rotation around the $\mathrm{C}-\mathrm{C}$ bond. $\mathrm{H}$ atoms were treated as riding, with $\mathrm{C}-\mathrm{H}$ distances of $0.95-1.00 \AA$ and $U_{\text {iso }}(\mathrm{H})$ values set to 1.5 or 1.2 times $U_{\text {eq }}$ of the carrier atom for methyl and other $\mathrm{H}$ atoms, respectively.

Data collection: COLLECT (Nonius, 1998); cell refinement: DENZO (Otwinowski \& Minor, 1997); data reduction: DENZO; program(s) used to solve structure: SHELXS86 (Sheldrick, 1986); program(s) used to refine structure: SHELXL97 (Sheldrick, 1997); molecular graphics: PLATON (Spek, 2003); software used to prepare material for publication: PLATON.

This work was supported in part (ALS and ML) by the Council for the Chemical Sciences of the Netherlands Organization for Scientific Research (CW-NWO) with financial aid from the Netherlands Technology Foundation (CW/STW 790.35.622).

\section{References}

Bolte, M., Beck, H., Nieger, M. \& Egert, E. (1994). Acta Cryst. C50, 1717-1721. Cremer, D. \& Pople, J. A. (1975). J. Am. Chem. Soc. 97, 1354-1358.

Duax, W. L. \& Norton, D. A. (1975). Atlas of steroid structure, Vol. 1. New York: IFI/Plenum. 


\section{organic papers}

Kooijman, H., Leemhuis, M., van Nostrum, C. F., Hennink, W. E. \& Spek, A. L. (2005). Acta Cryst. E61, o901-o903.

Leemhuis, M., Kruijtzer, J. A. W., Zhong, Z. Y., Feyen, J., van Nostrum, C. F., Hennink, W. E. (2005). In preparation

Leemhuis, M., van Steenis, J. H., van Uxem, M. J., van Nostrum, C. F., Hennink, W. E. (2003). Eur. J. Org. Chem. pp. 3344-3349.

Nonius (1998). COLLECT. Nonius BV, Delft, The Netherlands.
Otwinowski, Z. \& Minor, W. (1997). Methods in Enzymology, Vol. 276, Macromolecular Crystallography, Part A, edited by C. W. Carter Jr \& R. M. Sweet, pp. 307-326. New York: Academic Press.

Sheldrick, G. M. (1986). SHELXS86. University of Göttingen, Germany.

Sheldrick, G. M. (1997). SHELXL97. University of Göttingen, Germany. Spek, A. L. (2003). J. Appl. Cryst. 36, 7-13. 